\title{
Introduction: Technology and Families
}

\author{
Martin Covey, CFLE
}

\begin{abstract}
This Michigan Family Review explores the influence of technology on developing individuals and families. Technologies examined include domestic technologies, information technologies, and mass media. Individual development, family tasks, peer relationships, gendered work and communication, and family interventions are discussed through the lens of technological change.
\end{abstract}

Key Words: Families, technology, change

${ }^{1}$ Martin Covey is Associate Professor, School of Adult Studies, Spring Arbor University, 1550 E. Beltline S.E., Suite 230, Grand Rapids, MI 49506. Electronic mail may be sent to mcovey@arbor.edu.

Technological advances have changed the way people live their lives. How business is transacted, how people shop for goods and services, how people learn, even how people read are just a few of the specific activities that have been affected by technology (Colvin, Chonoweth, Bold \& Harding, 2004; Lamanna \& Riedmann, 2003). The fact that this article is offered in an electronic journal format is evidence of how technology has changed the way ordinary tasks are accomplished. For example, to read a journal such as this required an individual to take one of several possible courses of action. First, they could subscribe to a journal and read each copy as it arrived in the mail. Second, an individual could drive to a local university or public library, search the stacks, find the journal of interest, and read it there or check it out to take home. A third option would be possible if the interested individual knew someone who subscribed to the desired journal, thereupon they could perhaps request permission to 
borrow the copy to read. Because of advances in computer technology, the internet, and the World Wide Web, an individual interested in a topic, such as families, need only type in "Michigan Family Review" into an internet search engine, follow the link and access the desired journal at their leisure, without leaving home.

Advances in technology have changed the activity of reading itself. Reading was formerly a linear activity - starting at the front of an article or book and reading to the conclusion. Reading in an electronic journal, however, can be more cyclical and, in a sense, random. Embedded links within an internet article enable the reader to pursue interesting facts (http://www.familieswithpurpose.com), ask and answer new questions (http://www.familyfacts.org), or explore new ideas almost immediately.

In an ecological perspective (Bubolz \& Sontag, 1993), it can be understood that technology advances (in the development of a comprehensive road system, for example) have changed the important functions of what a government should be about in providing for its people. These same advances affect the types of businesses found in communities and how those businesses operate. These same advances then affect the types of goods families purchase, how many families have access to these goods, and how local families contribute to the local economy through the provision and purchase of goods they produce (Davies, 2002).

The changes wrought by the technological advancement of roads in American, as described by Davies, began in 1919. Continued advances in the American road and highway system reverberate through our society, communities, and homes. As sweeping as these changes have been and continue to be, they have occurred over the past 87 years. Advances in information and communication technologies, on the other hand, have transpired over a much shorter period of time and are more global and ubiquitous. A short 15 years, since the "birth of the World Wide 
Web" in 1991 (Marsh, n.d,), has seen cultures, businesses, families, and relationships change in more dramatic ways, if not in terms of the amount of change, at least in terms of the change's rapidity. Family research has yet to thoroughly explore the ramifications such rapid technological changes (Chesley, 2005).

This exploration is what this edition of Michigan Family Review is about. Two of the three articles focus on information technology, specifically the use of Internet Messaging and the use of the internet in an educational intervention with families. The other article examines how changes in domestic technology have influenced ideological and gendered understandings of task accomplishment in homes. The book review in this issue focuses on the much discussed issue of the impact of television on child development.

\section{References}

Bubolz, M. M., \& Sontag, M. S. (1993). Human ecology theory. In P.G. Boss, W.J. Doherty, R. LaRossa, W.R. Schumm, \& S.K. Steinmetz (Eds.), Sourcebook of family theories and methods: A contextual approach (pp. 419-447). New York: Plenum.

Chesley, N. (2005). Blurring boundaries? Linking technology use, spillover, individual distress, and family satisfaction. Journal of Marriage and Family, 27, 1237-1248.

Colvin, J., Chenoweth, L., Bold, M., \& Harding, C. (2004). Caregivers of older adults: Advantages and disadvantages of internet-based social support. Family Relations, 53, 40-57.

Davies, P. (2002). American road: The story of an epic transcontinental journey at the dawn of the motor age. New York: Henry Holt. 


\section{Introduction 4}

Lamanna, M. A., \& Riedmann, A. (2003). Marriages and families: Making choices in a diverse society. Belmont, CA: Wadsworth/Thomson.

March, D. (n.d.). History of the Internet. Retrieved November 4, 2006, from

http://www.netvalley.com/archives/mirrors/davemarshtimeline-1.htm 